\title{
CORONAVÍRUS E ODONTOLOGIA
}

\author{
Bruna Menegon Fabris \\ Letícia Boesing Külkamp \\ DOI: http://dx.doi.org/10.18616/intcov79
}

A pandemia atual, causada pelo coronavírus (covid-19) gera preocupações no mundo, as quais advêm do alto nível de contagio, mesmo possuindo um baixo índice de letalidade. Com isso, a quantidade de leitos torna-se insuficiente, sendo de maior eficácia o isolamento populacional, com o objetivo de reduzir a transmissão.

Esse afastamento é benéfico em relação à pandemia, porém pode acarretar em impactos econômicos, problemas na saúde individual, tanto físicos, como psicológicos. Estes ocorrem com o estresse e com o afastamento social, principalmente quando somado a doenças psicológicas já existentes. $\mathrm{O}$ isolamento pode ocasionar também o sedentarismo, a frequência da alimentação diária e com isso o aumento do consumo de sacarose e de carboidrato, resultando no acúmulo de resíduos na cavidade oral e, consequentemente, no aumento do índice de cáries.

Além da cárie, podem ocorrer problemáticas sem o auxílio no mo-

Os dentistas foram considerados os profissionais com maior risco de contagio, principalmente por conta do atendimento com grande proximidade do paciente, exposição à saliva, utilização instrumentos cortantes e dos aerossóis causados pela alta rotação, contendo fluidos como a saliva e o sangue. Por isso, antes da realização de atendimentos urgentes ou emergentes o profissio- 
nal deve analisar a temperatura corporal do paciente e aplicar um questionário direcionado.

Os cuidados indicados são a utilização de Equipamentos de Proteção Individual (EPIs), lavagem frequente das mãos, evitar aerossóis, usar peças rotatórias com sistema antirretorno, ter cuidado no manuseio de instrumentos perfurocortantes, realizar desinfecção de superfícies, proceder a esterilização dos equipamentos e dispositivos. Também é aconselhado o isolamento absoluto no paciente e bochechos antes do procedimento.

As orientações dos profissionais de saúde devem ser mais do que nunca seguidas com cautela, tanto as de prevenção ao coronavírus, como as recomendações gerais, como a escovação adequada, uma alimentação equilibrada, a prática de exercícios físicos, aproveitar esse tempo de retiro para o autocuidado e desfrutar de momentos em família.

\section{OBRAS CONSULTADAS}

TUNAAS, Inger. Doença pelo coronavírus 2019 (covid-19): uma abordagem preventiva para Odontologia. Rev. bras. de Odont., Rio de Janeiro, v. 77, e1766, 2020. Disponível em: http://revista.aborj.org.br/index.php/rbo/article/viewFile/1776/pdf. Acesso em: 31 mar. 2020 